\title{
Ontologia Marcina Śmigleckiego SJ
}

\section{Ontology by Marcin Śmiglecki, S.J.}

\begin{abstract}
Abstrakt
W artykule przedstawiono koncepcje ontologiczne Marcin Śmigleckiego (1563-1618), wybitnego teologa i filozofa z Zakonu Jezuitów. Jego najważniejszym dziełem jest Logica, która w Anglii miała kilka wydań. Szczególnej analizie została poddana oryginalna teza Śmigleckiego, że każdemu bytowi realnemu przysługują dwa sposoby istnienia - jako byt aktualny i potencjalny. W tym celu odwołano się do wypowiedzi we wspomnianej monografii polskiego jezuity, jak i prac innych badaczy jego dorobku filozoficznego. Oprócz pozytywnego wykładu w badaniach jego poglądów filozoficznych, przeprowadzono także ich analizę. Teza jezuickiego filozofa jest uzasadniona poprzez jego analizę logiczną pojęcia danego bytu. Kryterium logicznej spójności przyjmuje u niego postać kryterium ontologicznego. Spójność lub sprzeczność wyraża się, jego zdaniem, poprzez tzw. essentialia, którą możemy przetłumaczyć jako "cechy wewnętrzne" pojęcia danego bytu. Przyjęcie przez Śmigleckiego kryterium logicznej spójności $z$ jego ontologiczną interpretacją jest bardzo oryginalnym pomysłem, albowiem według polskiego jezuity, sprzeczność w porządku logicznym wskazuje na niemożność istnienia w porządku rzeczywistym. Zatem tym samym spójność w logicznym porządku uzasadnia tezę o istnieniu porządku ontologicznego. Tak więc polski jezuita sformułował ważny wniosek: można przejść od logicznego porządku intelektu do porządku świata empirycznego. Tezę Śmigleckiego wzmacnia fakt, iż o jego stanowisku
\end{abstract}


z uznaniem wyrażał się Leibniz i podobne wnioski w kwestii istnienia bytu realnego wyrażał wybitny filozof epoki nowożytnej Christian Wolff. Lecz aspekt podobieństwa poglądów Śmigleckiego do stanowiska innych filozofów wymaga dodatkowych badań. W artykule są także analizowane pojęcia umysłu i substancji w dorobku polskiego jezuity, które stanowiły główne obszary filozoficznych dociekań w epoce Śmigleckiego. Ważnym wnioskiem jest, iż w jego dorobku pojawiają się nie tylko zagadnienia istotne dla filozofii XVII wieku, lecz także jego twórczość cechuje oryginalność propozycji w ich rozumieniu i klarowność jego wykładu.

Słowa klucze: filozofia, logika, ontologia, byt myślny i realny, umysł

\begin{abstract}
In this article, the ontological concepts of Marcin Śmiglecki (1563-1618), an outstanding theologian and philosopher from the Jesuit Order are presented. His most important work is Logica, which had several editions in England. Śmiglecki's original thesis that every real being is entitled to two ways of existence, as actual and potential being, is particularly analyzed. For this purpose, we refer to the statements in the aforementioned monograph of the Polish Jesuit, as well as to the works of other scholars of his philosophical achievements. In addition to a positive lecture in the study of his philosophical views, we also conduct an analysis thereof. The Jesuit philosopher's thesis is justified by his logical analysis of the concept of the given entity. For him, the criterion of logical consistency takes the form of an ontological one. Consistency or contradiction is expressed, in his view, through the so-called Essentialia, which we can translate as "inner qualities" of the concept of the given entity. Śmiglecki's adoption of the criterion of logical consistency with its ontological interpretation is a very original idea, for according to the Polish Jesuit, a contradiction in the logical order indicates the impossibility of existence in the real order. Thus, by the same token, coherence in logical order justifies the thesis of the existence of an ontological order. As we can see, Polish Jesuit formulated an important conclusion: it is possible to move from the logical order of the intellect to the order of the empirical world. Śmiglecki's thesis is strengthened by the fact that Leibniz spoke highly of his position and Christian Wolff, an eminent philosopher of the modern era, expressed similar conclusions about the existence of real being. However, the aspect of the similarity between Śmiglecki's and the position of other philosophers requires additional research. The article also analyses the notions of mind and substance in the output of the Polish Jesuit, which constituted the main areas of philosophical inquiry in Śmiglecki's epoch. An important conclusion is that it is not only the issues relevant to seventeenth-century
\end{abstract}


philosophy that appear in his work, but the originality of his proposals in understanding them and the clarity of his interpretation.

Keywords: philosophy, logic, ontology, mental and real being, mind

\section{Wprowadzenie}

Truizmem jest stwierdzenie o wyjątkowym znaczeniu filozofii nowożytnej dla dorobku kultury intelektualnej cywilizacji Zachodu. Jednak warto przypomnieć w tym miejscu wypowiedź brytyjskiego matematyka i filozofa Alfreda Northa Whiteheada, że XVII wiek dla epoki nowożytnej filozofii i nauki był „stuleciem geniuszu”. A jednym z jego przejawów była także nowożytna scholastyka, rozwijana m.in. przez filozofów z Zakonu Jezuitów. Wśród nich ważną postacią jest polski jezuita Marcin Śmiglecki (1563-1618)2 , który dzięki studiom filozoficznym w Rzymie (1580-1586) i kontaktom z wieloma wybitnymi uczonymi jezuickimi, jak Robert Bellarmin (1542-1621), a przede wszystkim z Franciszkiem Suarezem (1548-1617), wniósł znaczny wkład do rozwoju tzw. drugiej scholastyki w epoce baroku. Polski filozof pozostawił w swoich pismach oryginalne, jak na jego czasy, poglądy dotyczące rozumienia bytu, co będzie przeanalizowane w niniejszym artykule, a zwłaszcza jego stanowisko w tej kwestii wyrażone w fundamentalnym dziele Logica ${ }^{3}$, które wykazuje wiele podobieństw do poglądów Gottfrieda W. Leibniza i Christiana Wolffa.

1 Alfred North Whitehead, Nauka i świat nowożytny, tłum. Maciej Kozłowski i Marek Pieńkowski OP, (Kraków: Wydawnictwo ZNAK, 1987), 67.

2 Na temat biografii i dorobku pisarskiego Marcina Śmigleckiego: Kazimierz Drzymała, Ks. Marcin Śmiglecki T.J. (Kraków: Prowincja Polski Południowej Towarzystwa Jezusowego, 1981); Roman Darowski, Filozofia w szkołach jezuickich w Polsce w XVI wieku (Kraków: Fakultet Filozoficzny Towarzystwa Jezusowego, 1994), 185-224.

3 Roman Darowski, Franciszek Bargieł, „Logica” Marcina Śmigleckiego. Wprowadzenie przegląd zagadnień - antologia tekstów, (Kraków: Akademia Ignatianum w Krakowie-WAM, 2016); Waldemar Voisé, „Marcin Śmiglecki: Logika (1618) Zamość, Oxford i perspektywy", Kwartalnik Historii Nauki i Techniki 39 (1994): 117-124. 


\section{Logica - podział i tematyka}

Pisma logiczne Arystotelesa zawsze były przedmiotem zainteresowań Śmigleckiego. Do naszych czasów zachował się obszerny rękopis jego wykładów z logiki, autorstwa jednego ze słuchaczy. Rękopis ten, liczący 600 stron, stanowi obszerny komentarz Śmigleckiego do Organonu Arytotelesa i Isagogi Porfiriusza ${ }^{4}$. Zamieszona w nim problematyka filozoficzna i osobiste przemyślenia jezuickiego filozofa wskazują na zamiar uporządkowania przez niego ważnej w studium filozofii i teologii problematyki logicznej. Z pewnością wykład ten był istotną motywacją do opracowania i wydania drukiem późniejszej Logiki ${ }^{5}$.

Monografia ta składa się z dwóch tomów i liczy łącznie 1631 stron. Całe dzieło zostało przez autora podzielone na 18 dysputacji, a te $z$ kolei na 184 kwestie $^{6}$. Ten ostatni podział jest bardzo klarowny i pomocny $\mathrm{w}$ orientacji $\mathrm{w}$ problematyce omawianej przez autora. Pierwszym tom jest podzielony na 11 dysputacji; Śmiglecki omawia w nim zagadnienie określone przez niego jako pierwsza czynność umysłu, przez które rozumie tworzenie pojęć. W poszczególnych dysputacjach Śmiglecki omawia kolejno: zagadnienie bytu myślnego, status logiki, pierwsze działanie umysłu, naturę uniwersaliów i ich ilość, rodzaje terminów, kategorie ontyczne, zagadnienie ilości, substancji i relacji oraz jakości.

Natomiast drugi tom, składający się z pozostałych 7 dysputacji, zawiera omówienie - używając również scholastycznych rozróżnień - drugą i trzecią operację umysłu. Przez pierwszą z nich Śmiglecki rozumie zagadnienie wartości logicznej zdania albo sądu, a następna to problem rozumowania $w$ logice. $W$ dalszych dysputacjach omawia zagadnienie dowodzenia i jego rodzaje, wartość nauki i jej wiedzy, naukę całościową; zaś w ostatniej dysputacji omawia problem definicji ${ }^{7}$. Jest to zatem problematyka sensu stricte logiczna, którą Śmiglecki rozpatruje w odniesieniu do dzieł logicznych Arystotelesa: Analityki pierwsze i Analityki wtóre,

4 Commentaria in Organum Aristotelis, sub insigni doctrina, pietate, et integritate, clarissimo viro, Martino Smiglecio, in celeberrima Vilnensi Academia, Philosophiae Professore scripta per me Stanislaum B[edensky]. Anno Domini 1586, ante quae Porphyrii Isagoge praesupponitur. Archiwum Archidiecezjalne w Poznaniu, Oddział Rękopisów i Starodruków Metropolitalnego Seminarium Duchownego (ul. Lubrańskiego 1), sygn. MS 147. Wydanie: Martinus Smiglecius, Commentaria in Organum Aristotelis, t. 1-2, red. Ludwik Nowak, (Warszawa: Akademia Teologii Katolickiej, 1987).

5 Martinus Smiglecius, Logica [...] selectis disputationibus et quaestionibus illustrata, pars 1, 2 (Ingolstadt: E. Angermaria, 1618).

6 Ludwik Nowak, „Logika dziełem życia”, w Kazimierz Drzymała, Ks. Marcin Śmiglecki T.J., (Kraków: Prowincja Polski Południowej Towarzystwa Jezusowego, 1981), 83-93.

7 Drzymała, Ks. Marcin Śmiglecki T.J., 86-91. 
O dowodach sofistycznych i Hermeneutyka. Jezuicki uczony omawia stanowisko Arystotelesa w rozwiązywaniu zagadnień filozoficznych, rozważa także ontologiczne podstawy filozofii Arystotelesa w jego Metafizyce i Kategoriach. Polski filozof jest otwarty na poglądy innych filozofów w wielu kwestiach, przytaczając poglądy Tomasza z Akwinu i współczesnych mu zwolenników Dunsa Szkota ${ }^{8}$.

Śmiglecki omawia w Logice także zagadnienie prawdy, która jest dla niego celem uprawiania filozofii. Jezuicki filozof przyjmuje klasyczną definicję prawdy w rozumieniu zbliżonym do Tomasza z Akwinu, lecz na uwagę zasługują jego dociekania związane z problemem definiowania prawdy. I dla polskiego jezuity ma ona charakter uniwersalny, stąd już samo pojęcie prawdy powinno umożliwić jej stosowanie jako zgodności do całej rzeczywistości w różnych aspektach. Dlatego rozważa on prawdę aplikowaną do bytu (prawda transcendentalna), epistemologii i teorii języka (prawda logiczna), nauki (prawda naukowa) i problemów moralnych (prawda moralna) ${ }^{9}$.

\section{Logica i ontologia}

Należy przede zauważyć, że wspomniane powyżej dzieło Śmigleckiego jest przede wszystkim poświęcone logice, a nie jest to podręcznik, czy też kurs metafizyki. A nawet pojęcie bytu myślnego jest dla polskiego jezuity przedmiotem logiki. Śmiglecki przejmuje bowiem pogląd swojego mistrza Suareza, który również określił byt myślny jako przedmiot logiki, a nie metafizyki, ale jak zauważa wybitny badacz nowożytnej scholastyki Jan Czerkawski, dla autora Disputationes metaphysicae „podstawowe zasady dotyczące tego bytu może w sposób kompetentny ustalić tylko i wyłącznie metafizyk" ${ }^{\prime \prime}$. A logiczne badania Śmigleckiego nad bytem myślnym miały, zdaniem Czerkawskiego, „doniosłe znaczenie dla zrozumienia dalszego rozwoju problematyki metafizycznej w XVII wieku"11. Autor Logiki był bowiem dobrze zaznajomiony z filozofią pierwszą wyłożoną przez Suareza w Disputationes metaphysicae, które są wyraźnym nawiązaniem do metafizyki Arystotelesa, ale z uwzględnieniem wpływów

8 Zbigniew Ogonowski, Filozofia szkolna w Polsce XVII wieku (Warszawa: PWN, 1985), 79-93.

9 Tomasz Pawlikowski, „Metafizyczne założenia koncepcji prawdy w Logice Marcina Śmigleckiego", Rocznik Filozoficzny Ignatianum 1 (2015): 7-28.

10 Jan Czerkawski, Humanizm i scholastyka: Studia z dziejów kultury filozoficznej w Polsce w XVI i XVII wieku (Lublin: Redakcja Wydawnictw KUL, 1992), 182.

11 Ibidem. 
Tomasza z Akwinu i Dunsa Szkota. Ponadto warto zauważyć, że hiszpański jezuita w wielu miejscach swojego dzieła odchodzi od myśli Stagiryty, przedstawiając własne koncepcje metafizyczne ${ }^{12}$.

Należy także zauważyć, iż oryginalność dzieła hiszpańskiego jezuity wychodzi poza ramy metafizyki, która bada byt jako byt. Lecz jest to także dzieło, które odegrało istotną rolę w procesie powstawania nowożytnej metafizyki i w obecnych badaniach tego zagadnienia „zgodnie wskazuje się na system metafizyki Francisco Suareza, wyłożony na stronach jego monumentalnego dzieła Disputationes metaphysicae, jako na bezpośrednią bazę dla wykształcenia się nowożytnej ontologii”' ${ }^{13}$. Wyrażone w poprzednim zdaniu stanowisko trzeba rozumieć w kontekście rozwoju metafizyki nowożytnej, jej transformacji w kierunku ontologii, co ostatecznie miało miejsce w filozofii Christiana Wolffa. I w tym znaczeniu należy rozmieć obecność ontologii w głównym dziele polskiego jezuity. Innymi słowy, w jego Logice są obecne, a nawet rozważane zagadnienia ontologiczne. Wprawdzie Śmiglecki nie zajmuje się ontologią bezpośrednio i pojęcie to nie pojawia w jego monografii, albowiem $\mathrm{w}$ jego czasach nie był w powszechnym użyciu ${ }^{14}$. Lecz problematyka ontologiczna, jak np. pytanie o status ontyczny pojęć, rzeczy, sposoby ich istnienia, zagadnienie substancji, status umysłu, są w dziele polskiego jezuity obecne. Logica Śmigleckiego nie jest bowiem typowym podręcznikiem, gdyż - zdaniem badaczy jego filozofii - problematyka logiczna w tym dziele „przeplata się z problematyką metafizyczną, ontologiczną, a nawet teologiczną"15. Należy bowiem zauważyć, że dla Śmigleckiego proces poznawania rzeczywistości odbywa się według pewnych zasad logicznych, których znajomość gwarantuje pewność w osiągnięciu prawdy o bycie we wszystkich jego aspektach. Zatem znajomość logiki jest punktem wyjścia do uprawiania filozofii zwłaszcza w dziedzinie teorii poznania i ontologii. W tym kontekście powinno się zwrócić uwagę na uwzględnienie przez polskiego filozofa dorobku Arystotelesa i Suareza

12 Rafał Choroszyński, „Franciszek Suarez jako protoplasta metafizyki nowożytnej”, Annales Universitatis Mariae Curie-Skłodowska Lublin - Polonia 1 (2005): 13-29.

13 Bogusław Paź, Filum cognitionis: Przemiany nowożytnej metafizyki w ontologię od Suareza do Kanta (Warszawa: IFiS PAN, 2019), 49-50.

14 Jako samodzielny termin „ontologia” sformułował Johannes Micraelius w drugiej połowie XVII wieku, w dziele Lexicon philosophicum terminorum philosophis usitatorum (1653). Natomiast został on spopularyzowany przez Christiana Wolffa w Philosophia Prima sive Ontologa. Methodo Scientifica Pertractata, Qua Omnis Cognitionis Humanae Principia Continentur (1736). Na temat genezy pojęcia „ontologia” w filozofii: Paź, Filum cognitionis.

15 Darowski, Bargieł, „Logica” Marcina Śmigleckiego, 58. 
w Logice, bowiem „Śmiglecki zawarł w swym dziele syntezę Arystotelesowskiej logiki oraz metafizyki Suareza"16.

Tematyka bytu pojawia się bowiem w pierwszym części Logiki i to już w pierwszej dysputacji, która jest podzielona na jedenaście kwestii. W dysputacji tej Śmiglecki odnosi się do treści ludzkiego umysłu, przez które rozumie on wszelkiego rodzaju myśli, jakie w nim występują, wytwory mentalne różnego rodzaju. Za swoiste byty można uznać również wszelkiego rodzaju nawet najbardziej niespójne fantazje, wyobrażenia, odczucia i fikcje itd. Stanowią one bowiem pewne obiekty obecne w ludzkim umyśle i dlatego przysługuje im status swoistej obiektywności, lecz tylko w granicach umysłu.

Rozważania Śmigleckiego w Logice wykraczają zatem zdecydowanie poza dociekania i analizy logiczne, albowiem, według badaczy Logiki polskiego jezuity, można w niej wyodrębnić warstwę dociekań metafizycznych, czy nawet ontologicznych, które są organicznie powiązane ze wspomnianymi badaniami logicznymi. Wypada być jednak bardzo ostrożnym przy interpretowaniu rozważań dotyczących bytu w Logice, albowiem wiele $z$ nich posiada specyficzne scholastyczne znaczenie. Trzeba zatem pamiętać, że Śmiglecki przypisuje wszelkim treściom umysłu istnienie obiektywne, lecz, jak wspomniano powyżej, nie zawsze jest to istnienie realne. Przez to pierwsze rozumie on bycie danej myśli, pojęcia, materia przedmiotu, które są obiektami obecnymi w umyśle ${ }^{17}$.

\section{Zagadnienie bytu myślnego}

Wyrazem aktywności ludzkiego intelektu jest byt nazwany przez Śmigleckiego „bytem myślnym” (ens rationis) ${ }^{18}$. Autor Logiki podaje jego następującą definicję: „Wyrażenie »byt myślny« oznacza bowiem to, co nie będąc bytem realnym istnieje tylko w umyśle"19. Śmiglecki podaje także metodę badań bytu myślnego. Według niego „naturę bytu myślnego możemy badać dwiema metodami: przeciwstawiając go bytowi realnemu, a następnie badając właściwy mu sposób istnienia, jaki posiada w umyśle [...]. Posługując się pierwszą metodą badań twierdzimy, że byt myślny przeciwstawia się bytowi realnemu nie w tym sensie, że jest on prostą

16 Paź, Filum cognitionis, 55.

17 Ogonowski, Filozofia szkolna, 84.

18 Gino Roncaglia, „Smiglecius on 'entia rationis”, Vivarium 33 (1995): 27-49.

19 Marcin Śmiglecki, O bycie myślnym, tłum. Tadeusz Włodarczyk, w Filozofia i myśl społeczna XVII wieku, cz. 2, red. Zbigniew Ogonowski, (Warszawa: PWN, 1979), 331. 
negacją bytu realnego (albowiem na swój sposób jest on bytem), ale z tego względu, że jest to tego rodzaju byt, który ani nie istnieje, ani też nie może istnieć realnie" 20 . Specyficzny charakter istnienia bytu myślnego polega zatem na tym, że to intelekt udziela mu istnienia. Innymi słowy, jest on w rozumieniu ontologii Arystotelesowskiej bytem przypadłościowym (akcydentalnym), którego źródło istnienia jest poza nim, właśnie w umyśle. Dla uściślenia tego zagadnienia, autor Logiki stwierdza: „Istnieniem realnym nazywam to istnienie, które ma miejsce poza umysłem, w rzeczywistości pozazmysłowej"21. W tym miejscu należy pamiętać, iż polski jezuita przyjmuje w epistemologii stanowisko realizmu poznawczego, iż człowiek poznaje niezależną od jego aktów poznawczych rzeczywistość, co jest poglądem typowym dla wielu filozofów w jego epoce. Lecz uzasadnienie realizmu Śmigleckiego jest dość oryginalne, bowiem wynika ono z uchwycenia fundamentalnej różnicy pomiędzy bytem myślnym a realnym, do czego jeszcze poniżej zostanie nawiązane.

Jezuicki uczony wyjaśnia również, jak powstaje w intelekcie byt myślny. Umysł jest dla Śmigleckiego strukturą autonomiczną i wytwarza pewien obraz, albo podobiznę poznawanego przedmiotu. Jest to zatem pewna jakość stworzona przez umysł ${ }^{22}$. O ile jakość ta jest powiązana z przedmiotem poza intelektem, jest obecnością przedmiotu w umyśle. Czyli przedmiot jest obecny w intelekcie poprzez swoją podobiznę, natomiast w przypadku bytu myślnego nie mamy takiego powiązania, lecz jedynie pewną konkretną treść obecną w umyśle ${ }^{23}$.

Wśród bytów myślnych należy wyodrębnić pojęcia charakteryzujące się pewnego rodzaju trwałością i jednością. Pojęcia te możemy także nazwać ogólnie bytami myślnymi. Można za nie uznać czyste pojęcia, modele i konstrukcje umysłu. Są one potrzebne w poznawaniu rzeczywiści, lecz ich rola sprowadza się - zdaniem autora Logiki - do aspektu pomocniczego w procesie poznawczym. Śmiglecki wyodrębnia w umyśle także zbiór pojęć, które określa jako pojęcia rzetelne, bowiem mają one związek z rzeczywistością poza umysłem ${ }^{24}$. Zagadnienie to jest przez niego rozważane w dysputacji IV, gdzie zajmuje się on problematyką powszechników (De naturis universalibus). Badając strukturę

20 Ibidem.

21 Ibidem.

22 Adam Aduszkiewicz, Od scholastyki do ontologii. Dwa studia (Warszawa: PAN IFiS, 1995), 57.

23 Ibidem, 58.

24 Nowak, „Logika dziełem życia”, 86. 
uniwersaliów Śmiglecki krytyczne odnosi się do idei platońskich, które odrzuca $^{25}$, przyjmując stanowisko Arystotelesowskie, iż uniwersalia są cechami rzeczy. Śmiglecki, podobnie jak Stagiryta, twierdzi, że nasze poznanie bytu zaczyna się od zmysłów ${ }^{26} \mathrm{i}$ ma charakter ogólny. Natomiast obiektywnie istniejąca rzeczywistość składa się z konkretnych rzeczy, które tworzą wielości i zbiory ${ }^{27}$, co wskazuje na przyjęcie przez Śmigleckiego pluralizmu metafizycznego. Polski jezuita jest w swoim rozumieniu rzeczywistości bliski poglądom Franciszka Suareza, przyjmując obiektywne istnienie jedynie konkretnych rzeczy. Lecz będąc uczniem Suareza, pozostawił wiele scholastycznych dystynkcji, które tamten odrzucał, jak materia i forma, istota i istnienie, oraz akt i możność ${ }^{28}$.

Przyjmując realistyczny punkt wyjścia w swoich rozważaniach logicznych, lecz także teoriopoznawczych, Śmiglecki nie mógł pominąć zagadnienia bytu samoistnego - substancji, odnosząc się tym samym do jednego z głównych problemów nowożytnej filozofii, tzw. sporu o substancję. Zagadnieniu substancji poświęca dysputację VIII (De substantia). Substancja to dla polskiego jezuity przede wszystkim pojęcie, które jest wytworem intelektu, ale ma jednak odniesienie i zakorzenienie w rzeczywistości pozazmysłowej. Zarazem zaznacza on, że substancja jest pojęciem wieloznacznym, analogicznym, wielokrotnie w filozofii dość niejasno ujmowanym. Śmiglecki przyjmuje jednak, że substancja sama $\mathrm{w}$ sobie jest bytem istniejącym (ens per se existens) i nie jest zależna od innych bytów (nec in alio, nec ab alio). Tak rozumiana substancja odnosi się do bytu Boga, ale w szerszym znaczeniu można ją odnosić do bytów przez Niego stworzonych. Śmilgecki przyjmuje zatem absolutne i względne pojęcie substancji jako bytu samoistnego.

\section{Zagadnienie bytu realnego}

Aktywność umysłu ludzkiego nie ogranicza się jedynie - zdaniem Śmigleckiego - do tworzenia bytów myślnych. Autor Logiki przyjmuje bowiem stanowisko Arystotelesa, iż poprzez zmysły intelekt ma kontakt z rzeczywistością, tym samym Śmiglecki przyjmuje istnienie relacji pomiędzy zmysłami a intelektem. Zatem może on także tworzyć pojęcia, które odpowiadają przedmiotom istniejącym poza umysłem. Jak

25 Smiglecius, Logica, p.1, 351.

26 Ibidem, 226.

27 Ibidem, 265-266.

28 Nowak, „Logika dziełem życia”, 89. 
już wiemy, dla odróżnienia tych pojęć od innych, autor Logiki stosuje także scholastyczne różnienie na byt mentalny (ens rationis) i byt realny (ens reale).

Z dotychczasowych rozważań autora Logiki wynika, że w intelekcie są obecne podobizny, które mogą być odzwierciedleniem różnych przedmiotów. W przypadku bytu myślnego jego przedmiot jest tożsamy $\mathrm{z}$ istniejącą $\mathrm{w}$ intelekcie podobizną. Natomiast $\mathrm{w}$ odniesieniu do bytu realnego możemy mówić o jego podobiźnie „z racji istoty przedstawionej i uprzedmiotowionej (obiectae et representantae) przez ową podobiznę" 29 . Wspomniana podobizna odsyła do realnego przedmiotu, co odróżnia byt realny od myślnego, czyli do ich różnicy istotowej (essentialiter), albowiem jak wyjaśnia jezuicki filozof: „byt myślny ze swej istoty domaga się tego, by istnieć w umyśle [...]. Natomiast istota bytu realnego nie wymaga, by istniał on w umyśle, gdyż ten sposób istnienia jest dla niego przypadłościowy" ${ }^{\prime 30}$.

Zasadniczą różnicę pomiędzy bytem myślnym a realnym widać na przykładzie odpowiedzi Śmigleckiego na pytanie: czy byt realny może stać się bytem myślnym i na odwrót? Jego odpowiedź jest zdecydowanie negatywna:

Byt realny może istnieć $w$ intelekcie, ale nie istnieje on w ten sposób w intelekcie, aby nie mógł istnieć poza intelektem, dlatego też nie istnieje on w intelekcie na sposób bytu myślnego, lecz na sposób bytu realnego. Byty realne w ten sposób istnieją w intelekcie, że mogą istnieć poza intelektem; byty myślne natomiast, $\mathrm{w}$ ten sposób istnieją w intelekcie, że poza intelektem istnieć nie mogą, jak np. chimera i centaur i inne byty niemożliwe (entia impossibilia) $^{31}$.

Autor Logiki utrzymuje zatem, iż różnica pomiędzy bytem myślnym a realnym wyraża się w ich sposobach istnienia. I aby zrozumieć tę różnicę, należy przeanalizować, jak Śmiglecki pojmuje istnienie bytu realnego. Istnienie bytu myślnego poza umysłem jest niemożliwe, zatem byt realny jest bytem możliwym. Jezuicki filozof przyjmuje znane w filozofii nurtu perypatetycko-scholastycznego stanowisko, iż w danym bycie możemy wyodrębnić akt i możność (potencjalność), albo jego istotę (essentia) $\mathrm{i}$ istnienie (existentia), lub sposób istnienia jego istoty (modus existendi).

29 Aduszkiewicz, Od scholastyki do ontologii, 59-60.

30 Śmiglecki, O bycie myślnym, 333.

31 Smiglecius, Logica, 2-3. Tłumaczenie cytuję za: Czerkawski, Humanizm i scholastyka, 184. 
Jako przykład Śmiglecki podaje w Logice różę. Do róży możemy zastosować ontyczne złożenie z istoty $\mathrm{i}$ istnienia. Róża bowiem posiada swoją istotę, jest bytem esencjalnym, lecz jakie są jej sposoby istnienia? Oczywiście róża może istnieć aktualnie, co jest jak najbardziej istnieniem realnym, i możemy do tej sytuacji stosować pojęcie bytu realnego. Jednak $\mathrm{z}$ uwagi na specyfikę swojego istnienia, róża $\mathrm{z}$ pewnością istnieje aktualnie $\mathrm{w}$ lecie i z całą pewnością jest to istnienie realne i aktualne. Lecz jak ma się sprawa $z$ istnieniem róży w zimie? Śmiglecki twierdzi, że również w zimie róża istnieje realnie, jako byt możnościowy. I ten sposób istnienia róży autor Logiki uważa za realny, czyli niezależny od podmiotu poznającego. Innymi słowy, róża może istnieć realnie jako byt aktualny albo byt możnościowy. Sposób istnienia możnościowego jako realnego wymaga jednak głębszego uzasadnienia: jaka jest natura bytu realnego, że przysługuje mu możnościowy, czyli nieaktualny modus istnienia niezależny od intelektu. Należy pokreślić, że dla Śmigleckiego aktualność i potencjalność nie są aspektami tego samego bytu, ale dwoma autonomicznymi sposobami istnienia.

Stanowisko polskiego jezuity w kwestii istnienia realnego danego bytu odbiega od poglądów Tomasza z Akwinu. Dla Akwinaty bowiem róża w lecie istnieje aktualnie, natomiast w zimie istnieje ona jako byt myślny (cum fundamento in re), natomiast dla Śmigleckiego jest ona w tej porze roku bytem realnym chociaż tylko możnościowym. Analogiczne sprawa ma się z innym przykładem podanym przez Śmigleckiego bytu istniejącego realnie możnościowo - „złotej góry”. Wprawdzie, jak zauważa autor Logiki, nikt jej nie widział, ale nie oznacza to, iż istnieje ona obiektywnie jedynie w intelekcie, lecz także realnie na sposób możnościowy ${ }^{32}$.

Wyjaśnienia wymagają stwierdzone powyżej różnice w stanowiskach Doktora Anielskiego i polskiego jezuity. Dla jasności warto powtórzyć, iż dla autora Logiki akt i potencjalność (możność) są dwoma sposobami istnienia realnego bytu, a nie jak dla Akwinaty elementami tworzącymi realny byt. Śmiglecki zradykalizuje swoje stanowisko, utożsamiając istnienie potencjalne bytu realnego z możliwością (possibilitas), przez co należy rozumieć niesprzeczne zaistnienie bytu realnego ${ }^{33}$. Na wspomniane różnice wpłynęła koncepcja bytu myślnego Tomasza z Akwinu, której można zarzucić niedopracowanie i to w stopniu niedostatecznym a następnie przejęta bez zmian przez późniejszych tomistów i nawet przejęcie stanowiska w tej kwestii ze skotyzmu, co miało swoje konsekwencje

32 Ogonowski, Filozofia szkolna, 84-85.

33 Czerkawski, Humanizm i scholastyka, 183-184. 
dla rozumienia bytu realnego w ówczesnym tomizmie, za którego przedstawiciela uważał się jezuicki filozof ${ }^{34}$.

Poruszone powyżej zagadnienie możliwości zaistnienia bytu realnego wskazuje na istnienie pewnej zasady logicznej, albo kryterium, dzięki któremu Śmiglecki może rozstrzygnąć, czy danemu bytowi przysługuje istnienie realne. Zatem, aby rozstrzygnąć ten problem, przejdźmy drogę rozumowania polskiego jezuity, powracając do pojęcia bytu myślnego i realnego. Śmiglecki, jak wiemy, wyjaśnia, iż swoista „istota” bytu myślnego wyraża pewną sprzeczność, jest ona fikcją istniejącą jedynie w umyśle, natomiast istota bytu realnego jest niesprzeczna, spójna. Wynika $\mathrm{z}$ tego, że realnie może istnieć jedynie to, co jest niesprzeczne. Śmiglecki odwołuje się zatem do logicznej zasady niesprzeczności, która ma - według niego - ważne konsekwencje ontyczne. Dla jezuickiego filozofa wszystko bowiem, co jest wewnętrznie niesprzeczne, jest realne (aktualnie lub możnościowo), i tym samym kryterium spójności logicznej przyjmuje postać kryterium ontycznego. Niesprzeczność lub sprzeczność wyraża się, według autora Logiki, poprzez tzw. essentialia, co można przetłumaczyć ,jako jakości istotowe" ${ }^{\text {"35 }}$. Byt realny tworzy swoją istotę (essentia) w sposób spójny, albo innymi słowy współmożliwy (compossibilia). Natomiast byt myślny zbudowany jest z jakości niewspółmożliwych, sprzecznych ze sobą (incompossibilia).

Badania Śmigleckiego nad bytem myślnym i realnym, które zostały ukierunkowane na analizę ich samej istoty, w dużym stopniu wykazują podobieństwo do analizy ejdetycznej i dotyczącej sposobów istnienia analizy modalnej. Ta pierwsza obecna jest $\mathrm{w}$ fenomenologii E. Husserla i R. Ingardena ${ }^{36}$. $Z$ pewnością analiza ejdetyczna wspomnianych fenomenologów wykazuje różnice w porównaniu $\mathrm{z}$ analizami istoty bytu dokonanymi przez polskiego jezuitę, lecz z uwagi na podobieństwa można go uznać za jej prekursora.

Przyjęcie przez Śmigleckiego kryterium logicznej niesprzeczności $\mathrm{z}$ jej ontyczną interpretacją jest stanowiskiem bardzo oryginalnym jak na jego czasy. Tomasz z Akwinu bowiem przyjmował także, że pojęcie wewnętrznie sprzeczne nie może odpowiadać realnemu przedmiotowi, lecz nigdy nie przyjął on zasady niesprzeczności - podobnie jak zapoczątkowany przez niego tomizm - jako kryterium do orzekania o realnej możliwości istnienia danego bytu. Akwinata zdecydowanie rozgraniczał bowiem możliwość na poziomie logicznym od możliwości istnienia

34 Ibidem, 187.

35 Ogonowski, Filozofia szkolna, 85.

36 Paź, Filum cognitionis, 59. 
realnego. Natomiast, jak konkludują Zbigniew Ogonowski i Jan Czerkawski, dla Śmigleckiego sprzeczność w porządku logicznym wskazuje na niemożliwość istnienia w porządku realnym, lecz niesprzeczność $\mathrm{w}$ porządku logicznym usprawiedliwia wniosek o istnieniu w porządku ontycznym; przynajmniej możnościowym ${ }^{37}$. Można zatem z logicznych rozważań polskiego jezuity sformułować inną ważną konkluzję, że jest możliwe przejście z porządku logicznego obecnego w intelekcie do porządku empirycznego, co stanowi wniosek niemożliwy do uzasadnienia dla Suareza, nota bene filozoficznego preceptora i mistrza Marcina Śmigleckiego ${ }^{38}$.

Metafizyczny aspekt logicznych rozważań polskiego jezuity można określić jako pewną modyfikację filozofii pierwszej Tomasza z Akwinu. Śmiglecki uważa, iż jest to jedna z postaci istnienia realnego. Jak wiemy, koncentruje się on na zagadnieniu istnienia bytów możliwych, którym także przypisuje realność. Ta ostatnia jest określona i zawarta w samej istocie rzeczy. Stanowisko metafizyczne Śmigleckiego jest określane jako skrajny esencjalizm, a stanowisko Akwinaty zostało przez Étienne’a Gilsona nazwane egzystencjalnym ${ }^{39}$.

\section{Status umysłu}

W powyższych rozważaniach wielokrotnie pojawiało się odniesienie omawianej problematyki do umysłu. Warto zatem zwrócić uwagę na zagadnienie umysłu, jego bytowości w poglądach jezuickiego filozofa. Problematyka związana z umysłem pojawia się w pierwszej części Logi$k i$, dysputacji II „O logice w ogólności”, w Kwestii I: „Czy przedmiotem logiki są czynności umysłu podatne na kierowalność". Zdaniem Romana Darowskiego i Franciszka Bargieła, jezuickich badaczy dorobku Śmigleckiego, „Logika - według niego - ma za przedmiot czynności ludzkiego umysłu, wytwarzające pojęcia, sądy i rozumowania, ale jako kierowalne przez czynnik nadzorczy, przez logikę, aby były prawidłowe. Czynności umysłowe w logice rozumie, wszystkie razem bez ich szczegółowienia $[\ldots]{ }^{\prime 40}$. „Kierowalność” to, zdaniem Śmigleckiego, ich zgodność z zasadami i prawami logiki ${ }^{41}$.

37 Ibidem, 86.

38 Aduszkiewicz, Od scholastyki do ontologii, 62.

39 Ogonowski, Filozofia szkolna, 86.

40 Darowski, Bargieł, „Logica” Marcina Śmigleckiego, 70.

41 Ibidem 71. 
Należy zauważyć, iż takie rozumienie przedmiotu logiki (analiza pojęć, sztuka argumentacji, rodzaje wiedzy i także umiejętność prowadzenia dyskursu filozoficznego) zakłada pewne rozumienie ludzkiego intelektu, które wskazuje na jego działanie, skoro dla Śmigleckiego logika odnosi się również do funkcjonowaniu ludzkiego umysłu, zasad jego działania ${ }^{42}$. W tak rozumianym przedmiocie logiki ujawnia się szczególne znaczenie intelektu, którego racjonalność wyraża się przede wszystkim w uporządkowaniu jego funkcji mentalnych. Tym samym intelekt, według Śmigleckiego, jest wyróżnionym bytem poprzez swoją wyjątkowość w procesie poznawania rzeczywistości, a szczególnie używania narzędzia, jakim jest logika i jej zasady.

Polski jezuita wielokrotnie wskazuje na twórczy charakter ludzkiego umysłu, co jest widoczne w dysputacji I, poświęconej bytowi myślnemu ${ }^{43}$. Działanie umysłu ujawnia wiele z jego istnienia w myśl scholastycznej zasady - agere sequitur esse, że działanie danego bytu wskazuje na jego istnienie. Można zatem przyjąć, że umysł dla Śmigleckiego jest autonomiczny i aktywny w poznawaniu rzeczywistości, co wyraża się tym, iż posiada on pewną niezależność w tworzeniu pojęć i wiedzy o otaczającym go świecie. Wprawdzie jezuicki uczony jest realistą i przyjmuje, podobnie jak Stagiryta, empiryczny punkt wyjścia w procesie poznawczym, to jednak uważa, iż podmiot poznający jest aktywny i twórczy, oraz zajmuje tym samym wyjątkowe miejsce wśród innych bytów.

Problem aktywności intelektu powraca w rozważaniach Śmigleckiego nad umysłem Boskim, szczególnie w odniesieniu do bytów myślnych: czy są one jedynie poznawane przez Boga, czy też przez Niego tworzone. Jezuicki uczony przychyla się do stanowiska filozofów scholastycznych, którzy argumentują, że byt myślny „Bóg tworzy we własnej Boskiej Myśli, a nawet istnieje on tam odwiecznie w postaci choćby myślnej relacji Bożego jestestwa do bytów stworzonych. Tak uczą Akwinata, Duns Szkot i wielu innych, a wśród nich Śmiglecki, który szeroko uzasadnia ten pogląd i odpiera zarzuty" ${ }^{\prime 4}$.

\section{Zakończenie}

Filozoficzne poglądy Marcina Śmigleckiego przyjmują za punkt wyjścia filozofię Arystotelesa i należy je uznać za reprezentatywne dla nurtu

42 Ibidem.

43 Darowski, Bargieł, „Logica” Marcina Śmigleckiego, 65-69.

44 Ibidem, 68. 
filozofii perypatetycko-scholastycznej. Jednak trzeba zauważyć, że nie są one typowymi komentarzami do pism Stagiryty, Tomasza z Akwinu, czy też innego przedstawiciela tego intelektualnego kierunku. Śmiglecki jest filozofem posiadającym własne oryginalne pomysły, do których należy przede wszystkim zagadnienie bytu realnego, ale także koncepcja aktywnego intelektu, którego działanie, np. autonomicznie tworzenie pojęć, odzwierciedla logika. O doniosłości filozoficznych badań polskiego jezuity świadczy uznanie, z jakim wyrażał się o nich Leibniz w swojej korespondencji ${ }^{45}$. Ważnym zagadnieniem ontycznych poglądów polskiego jezuity jest podobieństwo jego koncepcji bytu realnego do ontologii Christiana Wolffa, który przyjmował istnienie realne bytów możliwych na postawie niesprzeczności ich istoty. Zagadnienie to wymaga jednak oddzielnych badań porównawczych, aby uniknąć daleko idących konkluzji o podobieństwie stylów uprawiania filozofii przez wspomnianych myślicieli.

Na zakończenie warto powrócić do kwestii oryginalności autora Logiki jako twórcy nowych koncepcji i pomysłów w filozofii. Kwestia ta nie jest bowiem tak oczywista. Zdaniem Jana Czerkawskiego, polski jezuita wykazał się talentem i oryginalnością w umiejętnym przedstawianiu pomysłów filozoficznych wypracowanych przez Suareza, Dunsa Szkota i innych skotystów ${ }^{46}$. Z pewnością trafna jest jego konstatacja o zdolnościach dydaktycznych Śmigleckiego. Jednak w swoim znakomitym artykule ukazuje on poważne rozbieżności w kwestii rozumienia statusu ontycznego bytu przedmiotowego w szkole tomistycznej i w poglądach Dunsa Szkota oraz skotystów, którzy byli skłonni przypisywać bytowi przedmiotowemu (esse obiectivum) pewną większą realność jak bytowi myślnemu. Również preceptor Śmigleckiego - Suarez nie wypracował w tej kwestii jasnego stanowiska, raz bowiem skłaniał się do stanowiska tomistycznego, innym razem skotystów ${ }^{47}$. Właśnie w radykalnym esencjalizmie Śmigleckiego można dostrzec rozwiązanie tego problemu, co można uznać za oryginalny aspekt jego myśli filozoficznej.

45 Paź, Filum cognitionis, 58.

46 Czerkawski, Humanizm i scholastyka, 191.

47 Ibidem, 186-187. 


\section{Bibliografia}

\section{Źródła drukowane}

Smiglecius Martinus, Logica [...] selectis disputationibus et quaestionibus illustrata, pars 1, 2, (Ingolstadt: Drukarnia E. Angermaria, 1618).

Wolff Christian, Philosophia Prima sive Ontologa. Methodo Scientifica Pertractata, Qua Omnis Cognitionis Humanae Principia Continentur (1736).

\section{Książki i monografie}

Aduszkiewicz Adam, Od scholastyki do ontologii. Dwa studia (Warszawa: PAN IFiS, 1995).

Czerkawski Jan, Humanizm i scholastyka. Studia z dziejów kultury filozoficznej w Polsce w XVI i XVII wieku (Lublin: Redakcja wydawnictw KUL, 1992).

Darowski Roman SJ, Filozofia w szkołach jezuickich w Polsce w XVI wieku (Kraków: Fakultet Filozoficzny Towarzystwa Jezusowego 1994).

Darowski Roman SJ, Bargieł Franciszek SJ, „Logica” Marcina Śmigleckiego: wprowadzenie, przegląd zagadnień, antologia tekstów (Kraków: Akademia Ignatianum w Krakowie, WAM, 2016).

Drzymała. Kazimierz T.J., Ks. Marcin Śmiglecki T.J. (Kraków: Prowincja Polski Południowej Towarzystwa Jezusowego, 1981).

Nowak Ludwik, „Logika dziełem życia”, w Kazimierz Drzymała, Ks. Marcin Śmiglecki T.J., (Kraków: Prowincja Polski Południowej Towarzystwa Jezusowego, 1981), 83-93.

Ogonowski Zbigniew, Filozofia szkolna w Polsce XVII wieku (Warszawa: PWN, 1985).

Paź Bogusław, Filum cognitionis: Przemiany nowożytnej metafizyki w ontologie od Suareza do Kanta (Warszawa: IFiS PAN, 2019).

Śmiglecki Marcin, „O bycie myślnym”, tłum. Tadeusz Włodarczyk, w Filozofia i myśl społeczna XVII wieku, cz. 2, red. Zbigniew Ogonowski, (Warszawa: PWN, 1979), 331-351.

Whitehead Alfred North, Nauka i świat nowożytny, tłum. Maciej Kozłowski i Marek Pieńkowski OP, (Kraków: ZNAK, 1987).

\section{Czasopisma}

Choroszyński Rafał, „Franciszek Suarez jako protoplasta metafizyki nowożytnej”, Annales Universitatis Mariae Curie-Skłodowska Lublin - Polonia 1 (2005): 13-29.

Pawlikowski Tomasz, „Metafizyczne założenia koncepcji prawdy w Logice Marcina Śmigleckiego", Rocznik Filozoficzny Ignatianum 1 (2015): 7-28.

Voisé Waldemar, „Marcin Śmiglecki: Logika (1618). Zamość, Oxford i perspektywy", Kwartalnik Historii Nauki i Techniki 39 (1994): 117-124. 